\title{
Research Paper Determinants of fertilizer use in Maharashtra
}

See end of the paper for authors' affiliations

Correspondence to :

\section{A.R. Kulkarni}

Department of Agricultural Economics, Mahatma

Phule Krushi Vidyapeeth, Rahuri (M.S.) India Email : akhileshkulkarni 412@gmail.com
Paper History :

Received : 03.07.2018;

Revised :04.08.2018;

Accepted : 04.09.2018
ABSTRACT : The study was conducted for regionwise determinants of fertilizer use for major crops in Maharashtra. Regression model was used to study the determinants of fertilizer use in year 2013-14 for selected major crops viz., paddy, wheat, Rabi jowar, gram, red gram, oilseeds, groundnut and soybean, cotton and sugarcane in the area under study. At overall level in Maharashtra state determinants of fertilizer use of major crops showed that, irrigated area under crops showed positive relationship with fertilizer consumption in case of wheat, cotton and Adsali sugarcane. Gross family income received has significant positive association with the fertilizer consumption in groundnut and gram. Fertilizer expenditure incurred showed significant positive association with the consumption of fertilizers in red gram and cotton. The variable one year lagged price of crop output observed to be positive and significant in case of wheat and gram. Area under commercial crop showed significant influence on fertilizer consumption in red gram and Rabi jowar. Fertilizer expenditure in wheat and soybean crop, gross family income in cotton crop, one year lagged price in red gram and Rabi jowar crop and area under commercial crop in gram output had negatively significant effect output of these crops for varied reasons ranging from less preference for staple crop, excess inventory in the market and over use of resource resulting in declining in marginal product. The variable rainfall depicted a significant influence on fertilizer consumption in cotton and soybean crop. All these variables together explained 71 to 89 per cent of total variation in the consumption of fertilizes in all the selected crops.

KEY WORDS : Determinants, Fertilizer consumption

HOW TO CITE THIS PAPER : Dahiwade, P.M., Gavali, A.V. and Kulkarni, A.R. (2018). Determinants of fertilizer use in Maharashtra. Res.J. Agric. Eco. \& Stat., 9 (2) : 354-366, DOI : 10.15740/HAS/IRJAES/9.2/354366. Copyright@ 2018: Hind Agri-Horticultural Society. 